\title{
Challenges in Medical Education on Student Learning, Teaching and Assessments
}

\author{
Shanthi Vanka ${ }^{*}$, Amit Vanka ${ }^{2}$ and Othman Wali ${ }^{3}$ \\ 'Lecturer, Dentistry Program, Department of Preventive Dental Sciences, Ibn Sina National College for \\ Medical Studies, Jeddah - 22421, Saudi Arabia; shanthiamitvanka@gmail.com \\ ${ }^{2}$ Associate Professor, Dentistry Program, Department of Preventive Dental Sciences, Ibn Sina National \\ College for Medical Studies, Jeddah - 22421, Saudi Arabia \\ ${ }^{3}$ Vice-Dean, Dentistry Program, Department of Oral Basic and Clinical Sciences, Ibn Sina National \\ College for Medical Studies, Jeddah - 22421, Saudi Arabia
}

\begin{abstract}
Pandemic corona virus situation having progressed and become intensive by the end of academic year of so there is a big question in the minds of every teacher how to assess the students in medical institutes. The purpose of this review is to identify the various challenges in medical education the Universities are facing in learning, teaching and assessments and recommendations for coping strategies. The most pressing challenges that are emerging may include alternative assessments to the pen and paper assessments previously planned. In conclusion no matter what learning, teaching and assessment methods are employed by the various Universities each and every student has to have an individual responsibility to be self-accountable as they need to face the future with the knowledge they gain through these professional courses as online assessments are a significant technological advancement in today's era.
\end{abstract}

Keywords: Assessments, COVID 19, Learning, Teaching

\section{Introduction}

COVID 19 situation having progressed and become intensive by the end of academic year of so there is a big question in the minds of every teacher how to assess the students in medical institute. The UNESCO conference in April 2020 had shed light on the various coping strategies countries can use in policy making of learning, teaching and assessments not to delay the students' progression and at the same time not compromising on the quality ${ }^{1}$.

The purpose of this review is to identify the various challengesin medical education the Universities are facing in learning, teaching and assessments and recommendations for coping strategies. The most pressing challenges that are emerging may include alternative assessments to the pen and paper assessments previously planned. Any decision to post pone or cancel the exams has a very long term effect on the students. Self-assessments and home based assessments may be alternative strategies employed by the educational institutes to assess the students during the COVID 19 crisis $^{1}$. The concern of online assessments and the possible strategies to be considered to overcome them has been tabulated below.

The factors to be considered in orienting the faculties and students on the various online teaching and assessment strategies are graphically presented below in Figure 1 and 2.

${ }^{*}$ Author for correspondence 
Table 1. Concerns of online teaching and assessments and strategies to overcome them

\begin{tabular}{|c|c|c|}
\hline $\begin{array}{l}\text { Sl. } \\
\text { No. }\end{array}$ & Concerns & $\begin{array}{l}\text { Strategies to be considered } \\
\text { to overcome the concerns }\end{array}$ \\
\hline 1 & $\begin{array}{l}\text { Attitude of the } \\
\text { faculties }\end{array}$ & Orientation of the faculties \\
\hline 2 & $\begin{array}{l}\text { Cooperation from the } \\
\text { students }\end{array}$ & Orientation of the students \\
\hline 3 & Dishonesty & $\begin{array}{l}\text { Reinforcing the importance } \\
\text { of fair assessments to the } \\
\text { students }\end{array}$ \\
\hline 4 & $\begin{array}{l}\text { Psychomotor skills of } \\
\text { the students cannot be } \\
\text { assessed }\end{array}$ & $\begin{array}{l}\text { Objective Structured } \\
\text { Practical Exams (OSPE) } \\
\text { may be conducted }\end{array}$ \\
\hline 5 & $\begin{array}{l}\text { Internet access should } \\
\text { be available for all the } \\
\text { students }\end{array}$ & $\begin{array}{l}\text { Timings for assessments } \\
\text { have to be chosen as per the } \\
\text { usage of internet }\end{array}$ \\
\hline
\end{tabular}

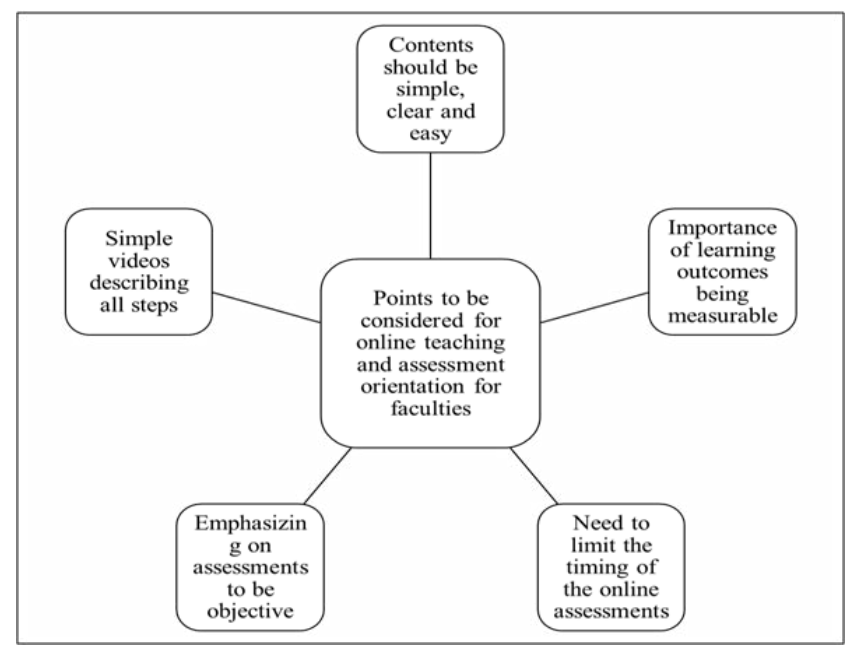

Figure 1. Points to be considered for orientation of faculties.

Some students and faculties believe that online exams are flawed ${ }^{2}$; self-accountability and ethical standards have to be followed by the students to overcome this barrier. The support from the families of the students also plays a very important role.

There are many platforms for medical Universities to conduct online teaching and assessments like MOODLE. MOODLE is a learning platform which has been designed to provide educators and learners a secure and an integrated system. It provides a collaborative environment for teaching and assessing through a comprehensive set of learner centric tools ${ }^{3}$.

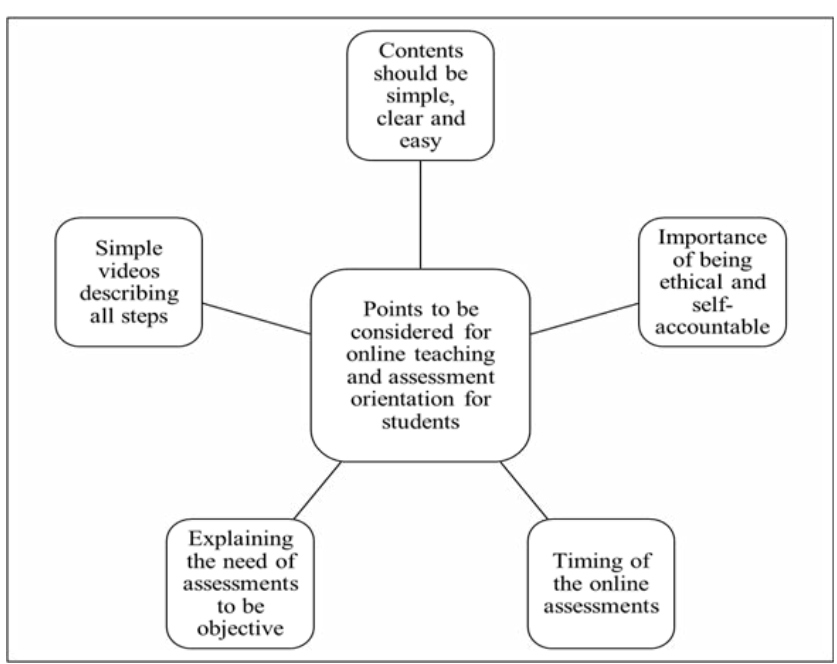

Figure 2. Points to be considered for orientation of students.

There are many Universities that are conducting modified online assessments than deferring assessments as a delay would be increasing the stress and burden on the students. There have been exceptional amendments that have been made trying not to compromise the academic standards of the students $s^{4}$.

Many other Asian Universities also have the online assessment barriers during the assessment crisis and it started early on. They are the first to have fought with experiments on online assessments. Large scale in person exams few were cancelled due to lack of an opportunity to conduct them ${ }^{5}$.

Singapore Institute of Technology was one University which had embraced technology enhanced teaching and assessments. They had fully implemented e learning platforms across the entire university for large classes. Strategies were put in place to make sure the learning outcomes were achieved and consistency was maintained across the University. Access to technology such as Zoom was made available for the faculties and students. The outcome of utilizing all these technologies was not to compromise any learning outcomes of the students ${ }^{6}$.

A University in UK also has developed similar plans as well being of the faculties and students are most warranted. Alternate assessments have been planned to replace the standard campus based exams ${ }^{7}$.

Few universities recognize the students assessments till now and based on that have declared the results and this is called as a "no detriment" principle. The benefit is that the students don't get effected by the various 
assessments that may not be as effective as the individual assessments carried out by the Universities earlier8.

In conclusion no matter what learning, teaching and assessment methods are employed by the various Universities each and every student has to have an individual responsibility to be self-accountable as they need to face the future with the knowledge they gain through these professional courses as online assessments are a significant technological advancement in today's era.

\section{References}

1. UNESCO. Exams and assessments in COVID-19 crisis: fairness at the centre. Accessed 18 April 2020 Available at https://en.unesco.org/news/exams-and-assessments-covid19-crisis-fairness-centre.

2. The Guardian. Medical students take final exams online for first time, despite student concern. Accessed 18 April 2020. Available at https://www.theguardian.com/education/2020/ mar/22/coronavirus-forces-medical-students-sit-finalexams-online.

3. Moodle. About Moodle. Accessed 19 April 2020. Available at https://docs.moodle.org/38/en/About_Moodle.
4. UCL. Teaching and assessments during the coronavirus (COVID-19) outbreak. Accessed 19 April 2020. Available at https://www.ucl.ac.uk/students/exams-and-assessments/ teaching-and-assessments-during-coronavirus-covid19-outbreak.

5. The World University Rankings. Asian universities face online assessment hurdles in virus crisis. Accessed 20 April 2020. Available at https://www.timeshighereducation.com/ news/asian-universities-face-online-assessment-hurdlesvirus-crisis.

6. The World University Rankings. Educating despite the Covid-19 outbreak: lessons from Singapore. Accessed 20 April 2020. Available at https://www.timeshighereducation. com/blog/educating-despite-covid-19-outbreak-lessonssingapore\#survey-answer.

7. University of Essex. Alternative assessment during the COVID-19 outbreak. Accessed 20 April 2020. Available at https://www.essex.ac.uk/student/exams-and-coursework/ alternative-assessment-during-the-covid-19-outbreak.

8. UCL. Teaching and assessments during the coronavirus (COVID-19) outbreak. Accessed 20 April 2020. Available at https:/www.ucl.ac.uk/students/exams-and-assessments/ teaching-and-assessments-during-coronavirus-covid19-outbreak. 